\title{
ARTERIOGRAPHY AND CAROTID ARTERY LIGATION IN INTRACRANIAL ANEURYSM AND VASCULAR MALFORMATION*
}

\author{
BY \\ I. S. WECHSLER, S. W. GROSS, and IRA COHEN \\ From the Neurological and Neurosurgical Services of the Mount Sinai Hospital \\ and the Montefiore Hospital, New York
}

Referring to carotid artery ligation Matas (1909) stated that "the possible occurrence of cerebral disturbance has invested a simple technical procedure with a gravity associated with but few operations". Statistics (Watson and Silverstone, 1939) compiled from cases in which carotid ligation was done for haemorrhage in the course of operations for advanced malignant neoplasms of the head and neck disclose an extremely high incidence of severe complications and a mortality of about $50 \%$. The statistics however are misleading and do not indicate the results to be expected following carotid ligation for intracranial aneurysms, vascular malformations, and arteriovenous fistulas.

John Abernethy (Garrison, 1913), John Hunter's immediate successor in London, ligated the common carotid artery for haemorrhage in 1798, but his patient died 30 hours later. Fleming (Keevil, 1949), a young surgeon in the Royal Navy, is credited with the first successful ligation of the common carotid artery on October 17,1803 . His patient attempted to commit suicide by cutting his throat while serving on H.M.S. Tonnant. Fleming treated the neck wound and his patient was convalescing satisfactorily when eight days later, on October 25, 1803 , during a severe paroxysm of coughing the carotid artery burst. Fleming cut down on the common carotid artery below the wound and tied it. The patient made an uneventful recovery.

During the first half of the nineteenth century ligation of the carotid artery was frequent, not only for haemorrhage and peripheral aneurysms but also for epilepsy, psychoses, and trigeminal neuralgia. In $1868 \mathrm{Pilz}$ collected 600 cases of ligature of the common carotid artery with a $43 \%$ mortality. In 1902 Horsley (quoted by Beadles, 1907) ligated the right common carotid artery in the neck for an intracranial aneurysm discovered during a cranio-

\footnotetext{
* Paper read at a meeting of the American Neurological Association, Atlantic City, June 13, 1950.
}

tomy for a suspected brain tumour. His patient was followed up for five years and was well at that time. Sporadic case reports of carotid ligation for intracranial aneurysm appeared in the literature from then until 1940, when Schorstein reported 60 cases of carotid ligation for intracranial aneurysms of spontaneous origin. Twenty-seven of the cases had previously been reported. The remaining 33 were contributed by members of the Society of British Neurological Surgeons. Rogers in 1947 reported ligation and division of the common carotid artery in seven cases of spontaneous subarachnoid haemorrhage due presumably to leaking aneurysms. Wechsler and Gross in 1948 advocated arteriography and ligation of the common carotid artery in subarachnoid haemorrhage due not only to leaking aneurysms but also in some cases of cerebral vascular malformations.

The introduction of cerebral angiography by Moniz in 1927 and reported fully in 1934 stimulated an interest in intracranial aneurysms and vascular malformations; the number of cases treated in most neurosurgical clinics has greatly increased. There is still, however, considerable controversy regarding the surgical management of these lesions. Dandy (1938), Jaeger (1950), and others advocated the direct intracranial exposure of most intracranial aneurysms and their obliteration either by ligating the neck of the aneurysm, trapping it between two clips, or placing strips of muscle on the aneurysmal wall. Rogers (1947b), and Wechsler and Gross (1948) have employed common carotid ligation in the treatment of intracranial aneurysms of the circle of Willis. The number of cases of cerebral vascular malformations which have been diagnosed has also increased greatly since the advent of cerebral angiography. There is also difference of opinion regarding the treatment of vascular malformations. Excision, radiotherapy, and carotid artery ligation have been advocated. Since 1939 we have carried 


\begin{tabular}{|c|c|c|c|c|}
\hline Case No. & Sex & Age & First Symptom & Clinical Summary \\
\hline 1. R.G. & F & 34 & Occipital pain & $\begin{array}{l}\text { Headache; stiff neck; L. 3rd nerve palsy int. and ext.; } \\
\text { hemiplegia ; mental state normal; ; fundi normal; C.S } \\
\text { negative; no convulsions. }\end{array}$ \\
\hline 2. L.S. & $\mathbf{M}$ & 23 & $\begin{array}{l}\text { Left frontal head- } \\
\text { ache }\end{array}$ & $\begin{array}{l}\text { Headache; stiff neck; eye signs normal; no hemiplegif } \\
\text { lethargic; fundi normal; C.S.F. grossly bloody; no con } \\
\text { vulsions. }\end{array}$ \\
\hline 3. M.C. & F & 54 & Cervical pain & $\begin{array}{l}\text { Headache; stiff neck; R. 3rd nerve palsy complete int. and exf } \\
\text { no hemiplegia; mental state normal ; slight blurring of fun } \\
\text { C.S.F. bloody; no convulsions. }\end{array}$ \\
\hline 4. J.M. & $F$ & 28 & $\begin{array}{l}\text { Loss of conscious- } \\
\text { ness }\end{array}$ & $\begin{array}{l}\text { Headache ; stiff neck ; partial L. 3rd nerve palsy ; no hemiplegid } \\
\text { normal mental state ; fundi normal ; C.S.F. xanthochromi } \\
\text { no convulsions. }\end{array}$ \\
\hline 5. B.B. & F & 47 & Syncope & $\begin{array}{l}\text { Headache; stiff neck; eye signs normal ; L. hemiplegia ; meng } \\
\text { state confused ; fundi normal ; C.S.F. xanthochromic ; cog } \\
\text { vulsions ; old C.N.S. lues. }\end{array}$ \\
\hline 6. L.M. & F & 21 & R. orbital pain & $\begin{array}{l}\text { Headache ; no stiff neck; R. exophthalmos and blindness; } \\
\text { hemiplegia ; mental state normal ; R. optic atrophy ; C.S } \\
\text { normal ; no convulsions. }\end{array}$ \\
\hline 7. F.N. & $F$ & 40 & Headache & $\begin{array}{l}\text { Headache ; stiff neck; eye signs normal ; L. hemiparesi } \\
\text { mentally confused and lethargic ; fundi normal ; C.S.F. bloody } \\
\text { no convulsions ; aphasia. }\end{array}$ \\
\hline 8. J.M. & F & 30 & L. headache & $\begin{array}{l}\text { Headache ; stiff neck ; partial L. 3rd nerve palsy ; no hemiplegio } \\
\text { confused mentally; fundi normal ; C.S.F. bloody; no } \\
\text { vulsions ; anomia. }\end{array}$ \\
\hline 9. M.K. & $\mathbf{F}$ & 46 & $\begin{array}{l}\text { Nocturnal head- } \\
\text { ache }\end{array}$ & $\begin{array}{l}\text { Headache ; stiff neck; eye signs normal ; no hemiplegia ; confus } \\
\text { mentally ; blurred discs; C.S.F. xanthochromic ; no } 980 \\
\text { vulsions. }\end{array}$ \\
\hline 10. M.W. & $\underset{\text { (Negro) }}{F}$ & 23 & Occipital pain & $\begin{array}{l}\text { Headache ; stiff neck ; eye signs normal ; L. hemiplegia ; stupo } \\
\text { fundi normal ; C.S.F. bloody ; convulsions ; bilateral Babegins } \\
\text { signs. }\end{array}$ \\
\hline 11. J.M. & F & 51 & Pain R. eye & $\begin{array}{l}\text { Headache ; no stiff neck; complete R. 3rd nerve paralysis ; } \\
\text { hemiplegia ; Witzelsucht ; fundi normal ; C.S.F. bloody; } \\
\text { convulsions; L. hyperreflexia. }\end{array}$ \\
\hline 12. M.F. & $\mathbf{F}$ & 46 & Headache & $\begin{array}{l}\text { Headache ; no stiff neck; L. pupil greater than R.; no heg } \\
\text { plegia ; mental state normal ; fundi normal ; C.S.F. xant } \\
\text { chromic ; no convulsions. }\end{array}$ \\
\hline 13. S.R. & $\mathbf{F}$ & 32 & Unconsciousness & $\begin{array}{l}\text { Headache ; stiff neck; both pupils fixed and dilated ; L. hem } \\
\text { plegia ; mental confusion and coma; normal fundi ; C.S } \\
\text { bloody; no convulsions; bilateral Babinski signs. }\end{array}$ \\
\hline 14. L.B. & $\mathbf{F}$ & 58 & Convulsions & $\begin{array}{l}\text { Headache ; no stiff neck; optic atrophy ; no hemipleging } \\
\text { mentally confused ; C.S.F. normal ; frequent convulsionn } \\
\text { incontinence. }\end{array}$ \\
\hline 15. P.S. & $\mathbf{F}$ & 60 & R. ptosis & $\begin{array}{l}\text { Headache ; no stiff neck; complete } R \text {. 3rd nerve palsy ; } \\
\text { hemiplegia ; mentally depressed; R. optic atrophy ; C.Sg } \\
\text { normal ; no convulsions ; R. corneal reflex absent. }\end{array}$ \\
\hline 16. C.B. & $\mathbf{F}$ & 46 & R. eye pain & $\begin{array}{l}\text { Headache; no stiff neck; complete R. 3rd nerve palsy ; } \\
\text { hemiplegia; normal mentally; fundi normal ; C.S.F. norma } \\
\text { no convulsions. }\end{array}$ \\
\hline 17. A.S. & $\mathbf{M}$ & 48 & $\begin{array}{l}\text { Loss of conscious- } \\
\text { ness }\end{array}$ & $\begin{array}{l}\text { Headache ; stiff neck; complete L. 3rd nerve palsy ; mentogl } \\
\text { confused and lethargic; blurred discs; C.S.F. xanthochrom } \\
\text { (pressure 430); convulsions ; R. facial, central. }\end{array}$ \\
\hline
\end{tabular}




\begin{tabular}{|c|c|c|c|c|}
\hline B.P. & Arteriogram & Site & Treatment & Result \\
\hline 13080 & Positive & Post.-commun. & Com. carotid ligated & $\begin{array}{l}\text { Ptosis improved. No head- } \\
\text { ache. Has remained well } \\
\text { for } 4 \text { years }\end{array}$ \\
\hline 12870 & Positive & $\begin{array}{l}\text { Bifurcation of anterior } \\
\text { and mid-cerebral }\end{array}$ & $\begin{array}{l}\text { Ligation and division L. com. } \\
\text { carotid }\end{array}$ & Improved. No follow-up \\
\hline 18095 & Positive & Post.-commun. & Ligation R. com. carotid & $\begin{array}{l}\text { 3rd nerve paralysis cleared up. } \\
\text { Remained well for over } 2 \\
\text { years (last follow-up) }\end{array}$ \\
\hline 11565 & Positive & $\begin{array}{l}\text { At origin L. mid. cerebral } \\
\text { (Fig. 2) }\end{array}$ & $\begin{array}{l}\text { Ligation and division L. com. } \\
\text { carotid }\end{array}$ & $\begin{array}{l}\text { Symptom-free and working } 2 \\
\text { years later }\end{array}$ \\
\hline 148100 & Positive & R. mid. cerebral & $\begin{array}{l}\text { Ligation and division R. com. } \\
\text { carotid }\end{array}$ & $\begin{array}{l}1 \text { year follow-up. No symp- } \\
\text { toms ; very slight } \mathrm{L} \text {. hemi- } \\
\text { paresis }\end{array}$ \\
\hline- & Positive & $\begin{array}{l}\text { Junction carotid and } \\
\text { ophthalmic }\end{array}$ & $\begin{array}{l}\text { Ligation com. } \\
\text { craniotomy with carotid ; } \\
\text { neck of aneurysm on }\end{array}$ & $\begin{array}{l}\text { Has remained well though } \\
\text { blind in R. eye. } 8 \text { year } \\
\text { follow-up }\end{array}$ \\
\hline $135 / 80$ & Positive & L. middle cerebral & Ligation L. com. carotid & - \\
\hline $108 / 70$ & Not done & - & $\begin{array}{l}\text { Ligation and division L. com. } \\
\text { carotid }\end{array}$ & Symptom-free 2 years \\
\hline $150: 100$ & Positive & R. middle cerebral & $\underset{\text { carotid }}{\text { Ligation and division com. }}$ & No symptoms 3 months later \\
\hline- & Positive & R. middle cerebral & $\begin{array}{l}\text { Ligation } R \text {. com. carotid and } \\
\text { craniotomy with clip on } \\
\text { neck of aneurysm }\end{array}$ & $\begin{array}{l}\text { Died } 4 \text { weeks later. No } \\
\text { necropsy }\end{array}$ \\
\hline $130 \cdot 70$ & Positive & Post.-commun. at carotid & $\begin{array}{l}\text { Ligation and division R. com. } \\
\text { carotid }\end{array}$ & $\begin{array}{l}\text { Marked improvement. Ptosis } \\
\text { improved. Recent case } \\
\text { (3.7.50) }\end{array}$ \\
\hline 12080 & Positive & R. middle cerebral & Ligation R. com. carotid & $\begin{array}{l}\text { No symptoms at time of } \\
\text { discharge }\end{array}$ \\
\hline 8050 & Positive & $\begin{array}{l}\text { Post.-commun. at junc- } \\
\text { tion with carotid }\end{array}$ & Ligation $R$. com. carotid & Died 9 hours later \\
\hline - & Positive & $\begin{array}{l}\text { L. anterior fossa } \\
\text { (Fig. 1) }\end{array}$ & $\begin{array}{l}\text { Ligation L. com. carotid ; } \\
\text { bi-frontal craniotomy }\end{array}$ & $\begin{array}{l}\text { Improved for } 10 \text { months after } \\
\text { ligation. Died } 10 \text { days after } \\
\text { craniotomy }\end{array}$ \\
\hline 220,140 & Not done & R. middle fossa & $\begin{array}{l}\text { Craniotomy and ligation } R \\
\text { com. and external carotid }\end{array}$ & $\begin{array}{l}\text { Ptosis cleared up; } 2 \text { year } \\
\text { follow-up }\end{array}$ \\
\hline $140: 70$ & Unsatisfactory & $?$ & Ligation R. com. carotid & $\begin{array}{l}\text { Immediate relief of pain ; } 3 \text { rd } \\
\text { nerve palsy improved }\end{array}$ \\
\hline 13070 & Positive & L. internal carotid & $\begin{array}{l}\text { Ligation and division L. com. } \\
\text { carotid }\end{array}$ & $\begin{array}{l}6 \text { hours later } R \text {. hemiplegia } \\
\text { and aphasia } 5 \text { months later } \\
\text { much improved }\end{array}$ \\
\hline
\end{tabular}


out a more or less uniform policy, employing carotid artery ligation in most cases of subarachnoid bleeding whether due to a leaking aneurysm or rupture of a vascular malformation. In nearly all cases the lesion was verified by arteriography and, in a few, by direct intracranial exposure. Our experience includes traumatic and spontaneous intracranial arteriovenous fistulas, in which the problem of treatment is somewhat similar.

\section{Aneurysms of the Circle of Willis}

Our material consists of 17 cases (Table I). All were treated by carotid artery ligation, and in four cases the lesion was also exposed intracranially. In two cases the aneurysm had a neck small enough to permit ligation with a silver clip. In the early cases, after an arteriogram, the common carotid artery was merely ligated in continuity with a silk ligature after a preliminary temporary occlusion for ten minutes or longer had been well tolerated. In seven cases the common carotid was divided after double ligation and the cut ends were transfixed.

In considering ligation of the carotid artery several questions must be answered: What are the dangers of carotid ligation? If ligation is decided upon, shall it be the common or internal carotid ? Should one merely ligate, or doubly ligate and divide? Finally, how effective is ligation in the treatment of intracranial aneurysms?

Although there are many variations in the circle of Willis, it is incomplete in less than $10 \%$ of specimens examined (Padget, 1944). Variations in the size of the vessels are more common. In a series of adult brains studied by Fetterman and Moran (1941), the posterior communicating arteries were "threadlike" in $20 \%$ of 200 cases. The anterior communicating artery may be duplicated in some cases : in others it is absent, the circle being completed by fusion of the anterior cerebral arteries. The arteries of the circle of Willis serve as anastomotic channels for an alternate course of blood flow when obstruction of one of the main vessels occurs. The circle is not an equalizer or distributing station (Rogers, 1947a). Sweet and Bennett (1948) showed that in man the systolic pressure falls to $50 \%$ and the pulse pressure to $25 \%$ of their original levels in the distal portion of the internal carotid artery when the vessel is occluded in the neck. They also found that significant retrograde flow from the external to the internal carotid artery usually does not occur when the common carotid alone is occluded. This refutes the often repeated statement in the literature regarding collateral circulation through the external carotid artery when the common carotid is ligated.
The dangers of carotid artery ligation may be divided into the early and the late. The immediate complications result from cerebral ischaemia. Toleration of digital compression of the common or internal carotid arteries in the neck (Matas test) for a period of ten minutes has been taken to indicate an adequate collateral circulation, but Sweet and Bennett have shown that this test is grossly unreliable.

We have carried out nearly all of our carotid artery ligations under local anaesthesia. Before ligation the artery is always occluded temporarily for at least ten minutes when the patient is carefully observed for the development of new neurological disturbances. In addition, we now take an electroencephalogram during temporary occlusion of the common and internal carotid arteries when the vessels are directly exposed under local anaesthesia. Our results will be reported later. In 30 carotid artery ligations, 28 of the common and two of the internal carotid, there were no immediate complications. Delayed complications occurred in four of our patients : one in a case of aneurysm of the internal carotid, one of traumatic arteriovenous fistula, one of spontaneous arteriovenous fistula, and one of vascular malformation. In the patient with an aneurysm of the intracranial portion of the internal carotid artery the ligation resulted in some permanent neurological disturbance.

\section{Case Report}

The patient was a man aged 48 (Case 17). Several years previously he suddenly lost consciousness, and a
lumbar puncture showed a bloody cerebrospinal fluid. He gradually improved, though he had diplopia for several weeks. He remained well until three weeks before his second hospital admission when he suddenly developed headache, vomiting, and ptosis of the left upper lid. He had a stiff neck at this time, and it seemed quite evident that he had a leaking intracranial aneurysm. He was confused and complained of severe headache. The fundi showed blurred disc margins. There was a complete internal and external left third nerve paralysis and a right central facial weakness. On the third hospital day he had a severe generalized convulsion. Four days later an arteriogram was taken under local anaesthesia. Although the films were not entirely satisfactory, they indicated an aneurysm of the left internal carotid artery. The common carotid artery was occluded for ten minutes with a tape. The patient had been restless and uncooperative throughout the entire procedure, but as no new neurological abnormalities developed the common carotid artery was doubly ligated and cut between the ligatures. About six hours later he developed a right hemiparesis and aphasia. Gradual improvement began in a few days. Four months later he had slight residual weakness of the right hand and some anomia, but was in excellent 
general health, free of headache, and the left ptosis was improving.

Schorstein (1940) discussed the theories regarding delayed complications resulting from carotid artery ligation. The embolic theory has been the one most often quoted. It assumes that a thrombus forms at the site of ligature and that detached pieces of the thrombus lodge in the branches of the circle of Willis. There has been very little pathological evidence to support this theory. Another theory assumes that a thrombus extending upwards forms in the ligatured vessel. Spasm of the carotid artery and its branches distal to the site of ligature has been advanced as a possible cause of immediate and delayed complications. While this theory is plausible, there has been no convincing experimental evidence to substantiate it.

There is considerable controversy in the literature regarding which vessel to ligate. Most authors state that ligation of the internal carotid artery is much more hazardous than ligation of the common carotid artery. The assumption is that occlusion of the common carotid reduces blood flow through the internal carotid by only about $50 \%$ because of retrograde collateral circulation through the external carotid, but the work of Sweet and Bennett (1948) contradicts this contention. Nevertheless, the collected experiences in the reported cases bear out the impression that ligation of the internal carotid is much more likely to result in cerebral disturbances or death. The explanation for this is not entirely clear. Schorstein believes that cerebral disturbances after carotid ligation are most likely due to failure of the systemic circulation. The high incidence of complications when the carotid artery is ligated for haemorrhage in the course of an operation for a tumour in the neck, or when ligation is done in old or debilitated individuals, supports this view.

The advantages of dividing the occluded vessel between ligatures are probably more theoretical than real. Rogers (1947b) believes that by dividing the occluded vessel the accompanying sympathetic nerves are also severed and vasospasm in the distal arterial segment and its branches is avoided. Embolism is less likely after division of an occluded artery, since the pumping action of the pulse beat at the ligature site is avoided and the free distal arterial segment shuts down on the clot.

In 17 cases in which carotid ligation was used in the treatment of intracranial aneurysms of the circle of Willis there were three deaths. In Case 10 (previously reported; Wechsler and Gross, 1948) the patient was critically ill. She had had two convulsions, a left hemiplegia with forced deviation of the eyes to the right, and a grossly bloody cerebrospinal fluid under a pressure of $300 \mathrm{~mm}$. Arterio- graphy showed a berry aneurysm springing from the middle cerebral artery near its junction with the internal carotid artery. The right common carotid artery was ligated in the neck. Although spinal puncture showed no evidence of fresh bleeding the patient continued in stupor. Four days later an intracranial approach disclosed the aneurysm to have a neck small enough to permit the application of a silver clip. The patient slowly improved for almost one month when she suddenly died. Necropsy was not permitted so we are at a loss to explain her death. The second patient (Case 13) was moribund at the time of arteriography and carotid artery ligation, and she died nine hours later. The third patient (Case 14) had a huge subfrontal mass which, from the history and pneumoencephalogram, was thought to be a tumour. Bifrontal exploration showed a large midline aneurysm extending more to the left (Fig. 1). It was at least $3 \mathrm{~cm}$. in diameter. Arteriography and left common carotid ligation were followed by cessation of her previous seizures, but her mental condition deteriorated. Ten months later the old craniotomy wound was reopened and the aneurysm was wired. She failed to improve and died 11 days later.

Of the 14 patients who were discharged from the hospital improved, ten had bloody or xanthochromic cerebrospinal fluid on admission to the hospital. Of these, follow-ups from three months to over two years are available in seven, and they are all well or improving. We first saw one patient (Case 1) about one year after her first attack of subarachnoid haemorrhage. She complained of head pain and had a complete left oculomotor nerve paralysis. Following arteriography and ligation the head pain disappeared and the eye signs cleared up. She has remained well and active for over four years. In every case where the third cranial nerve was involved there was either improvement or complete restoration of function. We do not know of any patient who has had subarachnoid bleeding subsequent to carotid ligation for intracranial aneurysm. Four patients who were improved at the time of discharge from the hospital failed to report to the follow-up clinic (Cases 2, 7, 12, and 16).

In Case 8 carotid ligation was probably a lifesaving measure. This patient, a 30 -year-old woman, had a sudden onset of vomiting and loss of consciousness for 15 minutes. Four hours later she had severe left-sided head pain. She was confused. The headache, nausea, and vomiting continued for several days. She had neck rigidity and a bloody spinal fluid. She improved for a few days and then began to have attacks of anomia and numbness of the right hand. She suddenly developed excruci- 


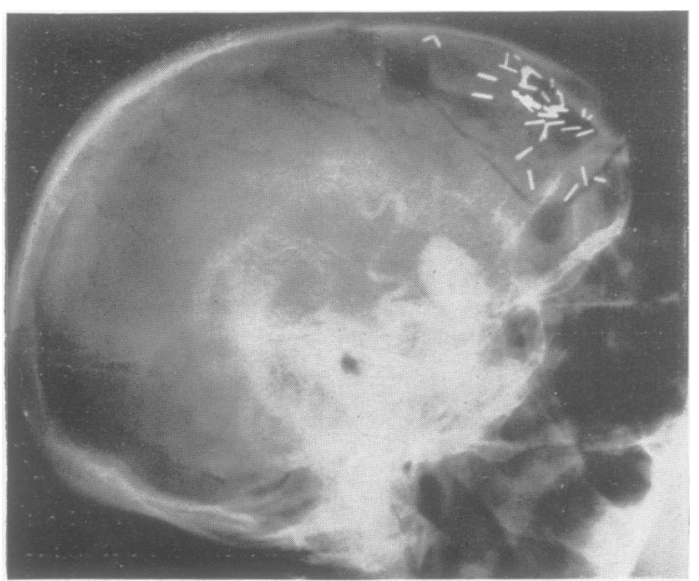

FIG. 1

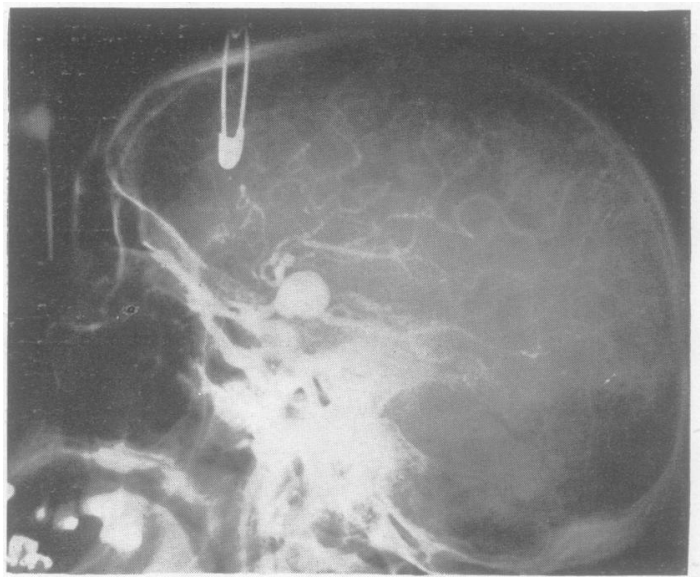

FIG. 2

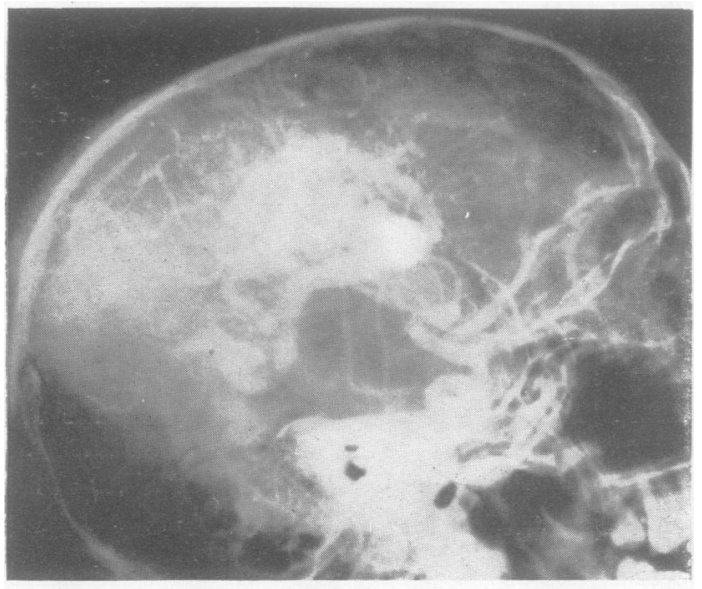

FIG. 3 ating left-sided head pain, and dilatation of the left pupil and left ptosis, and the nuchal rigidity increased. At this time the patient appeared critically ill. The left common carotid artery was doubly ligated and divided. One hour later she was free of headache. She improved rapidly and has remained well for two years.

The ocular signs in aneurysms of the circle of Willis have received a great deal of attention (Walsh and King, 1942). Eye pain associated with ptosis and dilatation of the ipsilateral pupil should lead to a suspicion of an aneurysm of the anterior portion of the circle of Willis. If, in addition, there is evidence of subarachnoid bleeding in the cerebrospinal fluid the diagnosis of aneurysm is almost certain. Complete paralysis, both internal and external, of the oculomotor nerve was present in six of our 17 patients. One patient (Case 8) developed slight ptosis and dilatation of the ipsilateral pupil while in the hospital. This cleared up shortly after common carotid artery ligation. In Case 4 ptosis and dilatation of the pupil also developed during observation. The arteriogram showed an aneurysm at the origin of the middle cerebral artery (Fig. 2). The ocular palsy persisted for two months. When the patient was seen two years later there was no longer any sign of oculomotor weakness.

In 12 of our patients the cerebrospinal fluid was either bloody or xanthochromic. There was a report of a bloody fluid from a recent previous hospital admission in Case 1, although her cerebrospinal fluid was clear and colourless at the time of carotid artery ligation. She applied for treatment because of the ptosis and eye pain.

No unusual reactions to arteriography with $35 \%$ diodrast were observed in any of our patients who had bloody or xanthochromic cerebrospinal fluids. Either common carotid artery ligation or ligation and division was done as soon as the wet $x$-ray films were read. The youngest patient in this series was 21 , the oldest 60 . The average age was 40.5 years. There were only two males in this series. The higher incidence of intracranial aneurysms in females is not peculiar to our series. In cases reported from other clinics aneurysms were also found to occur with greater frequency in females. In Hamby's (1948) series of 130 patients with subarachnoid haemorrhage of presumed aneurysmal origin there were 75 women and 55 men. Eight of

Fig. 1.-Large aneurysm in left anterior fossa (Case 14). FIG. 2.-Aneurysm of middle cerebral artery (Case 12).

FIG. 3.-Arteriogran, $x$-ray therapy, showing vascular malformation (Case 18). 
13 intracranial aneurysms proved at necropsy by Dial and Maurer (1937) occurred in women.

\section{Vascular Malformations}

Until the recent widespread use of cerebral angiography, vascular malformations of the brain were rarely reported (Wechsler and Gross, 1948). In their monograph published in 1928 Cushing and Bailey reported 16 cases, an incidence of slightly over $1 \%$ of their verified intracranial tumours. Although in recent years numerous references to these lesions have appeared, opinion regarding their treatment has not yet crystallized. There has been much difference of opinion also as to whether cerebral vascular malformations should be classified with neoplasms of the brain, with the congenital anomalies or with the hamartomas (tumour-like anomalies). Olivecrona and Riives (1948) recently reported their experiences with 60 cases of " arteriovenous aneurysms of the brain ", their term for the lesion under discussion. They advocate the radical removal of vascular malformations. In 43 patients so treated there were four deaths.

Our own material consists of nine cases : five women and four men (Table II). The youngest was 17 when first seen by us, the oldest 56. All but two had had subarachnoid bleeding sometime during the course of their illness and five had bloody or xanthochromic cerebrospinal fluid during their current hospital admission. One patient (Case 20) had had an attack of subarachnoid bleeding eight years previously. This was the first evidence of his abnormality. Except for occasional headache he remained well for seven years when he began to have petit mal attacks. About one year later he had a grand mal seizure. An angiogram done at that time revealed an extensive vascular malformation in the left frontal area. His cerebrospinal fluid was normal during his hospital stay. Case 22 and Case 24 had no evidence of subarachnoid bleeding, and their cerebrospinal fluids were clear and colourless during their periods of hospital observation.

Convulsions were present in seven of our patients. Three patients were admitted to the hospital for investigation because of seizures. Arteriography was done in eight patients. In Case 22 an extensive vascular malformation was discovered after a bone flap had been elevated for a presumed brain tumour.

Fig. 4.-Vascular malformation in parietal area (Case 21).

Fig. 5.-Arteriogran, after craniotomy, showing vascular malformation (Case 24).

Fig. 6.-Traumatic arteriovenous fistula (Case 28).

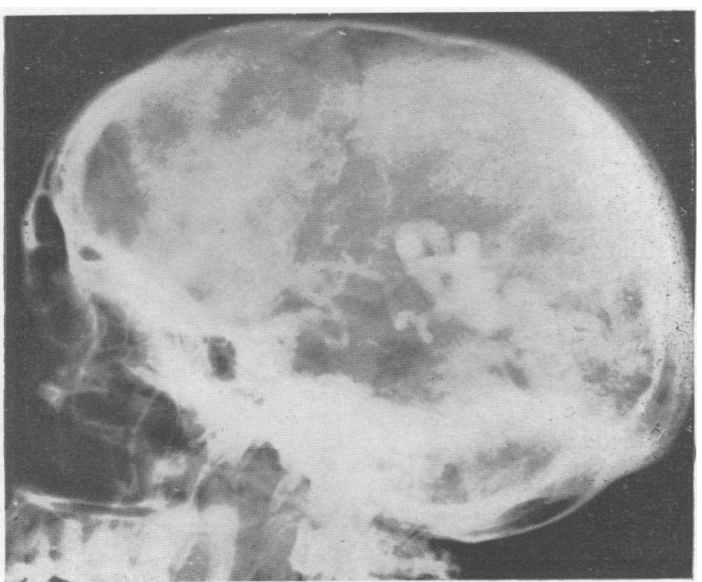

Fig. 4

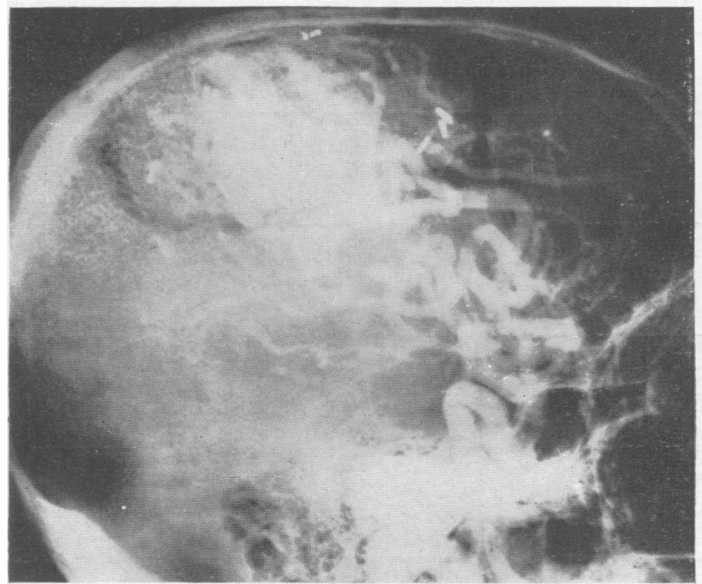

Fig. 5

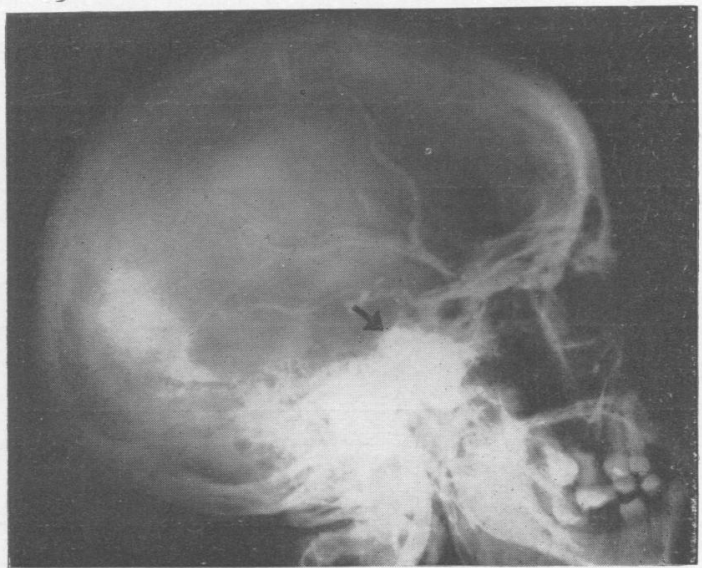

Fig. 6 
TABLE II. VASCULAR

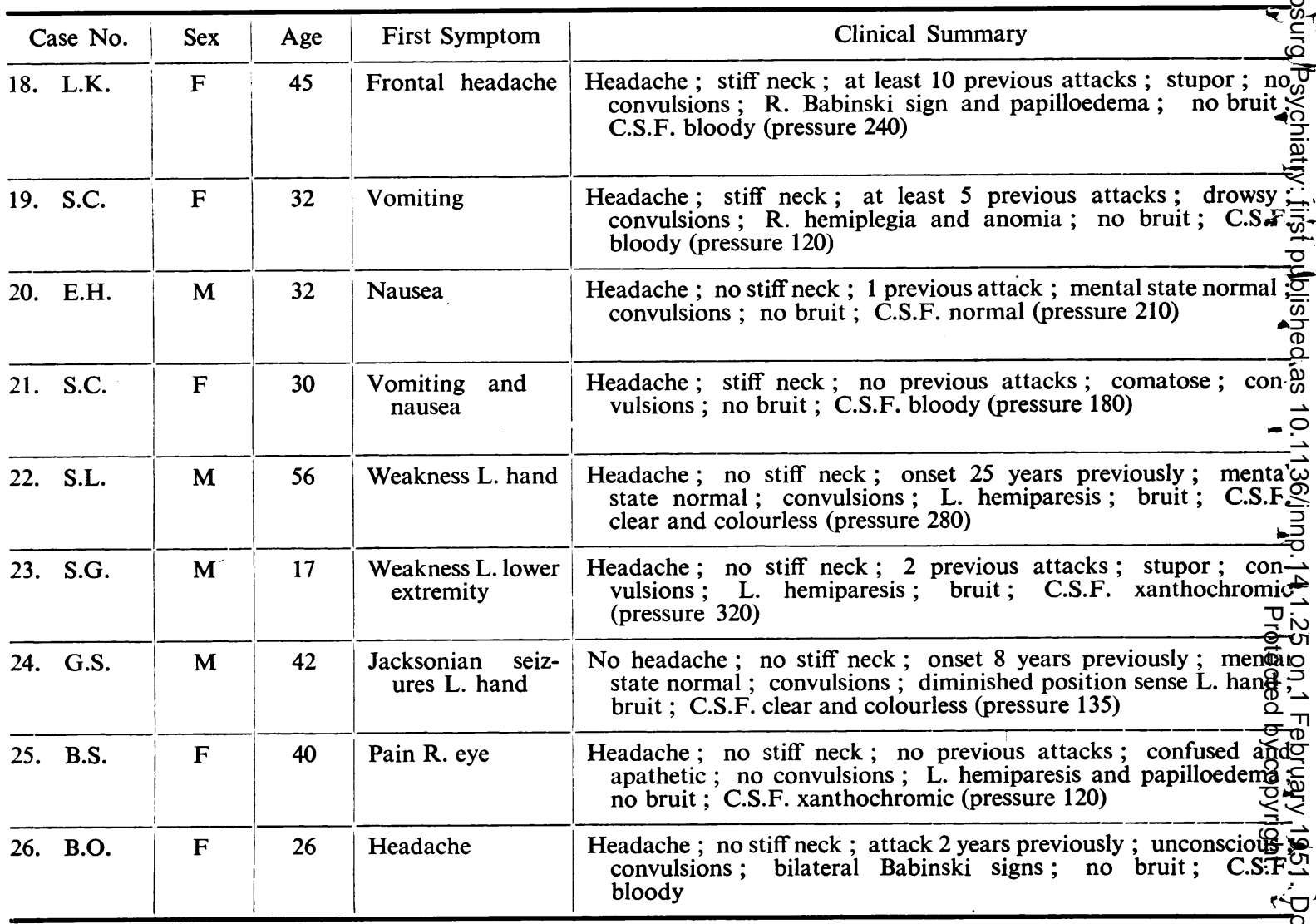

TABLE IIIि

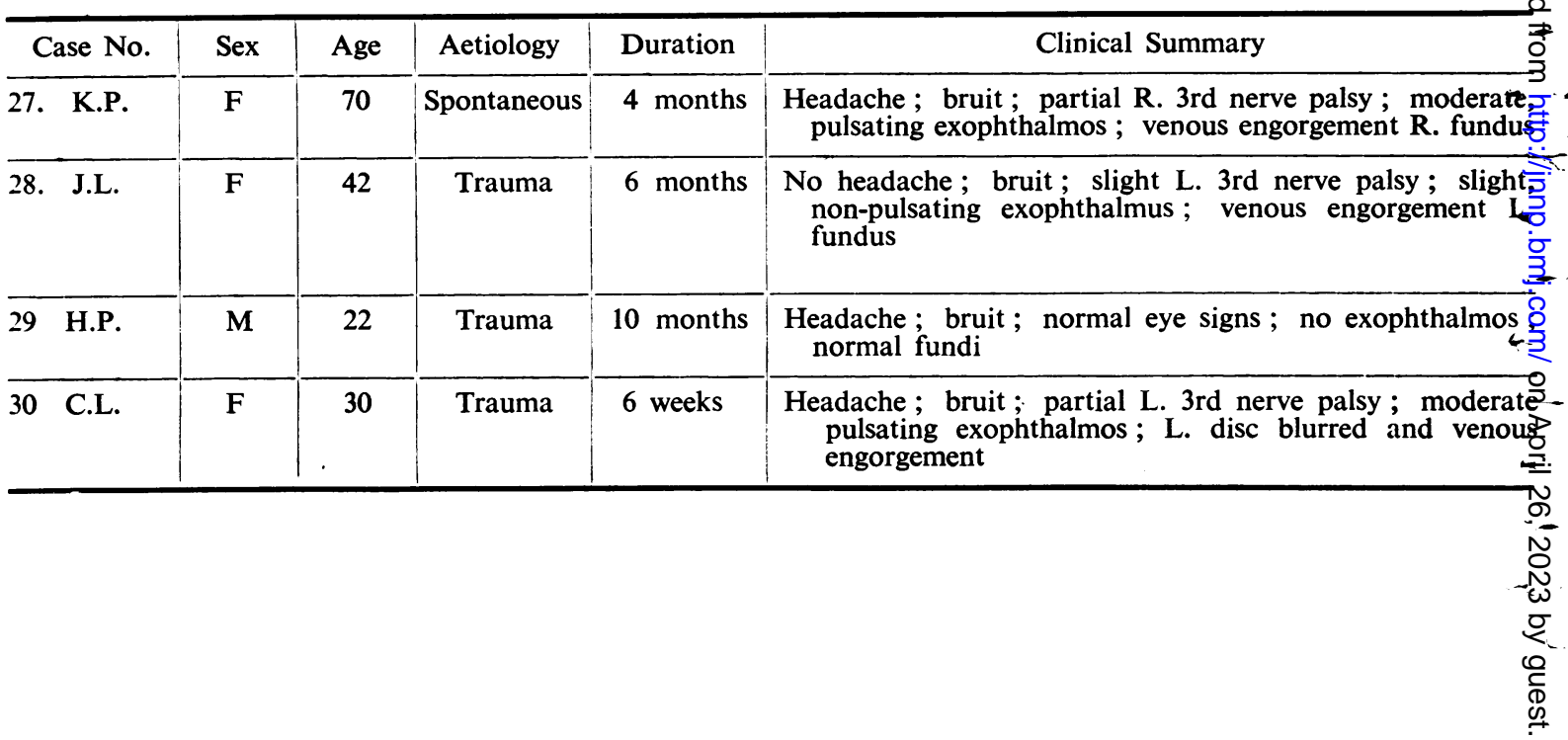


ALALFORMATIONS

\begin{tabular}{|c|c|c|c|c|}
\hline B.P. & Arteriogram & Site & Treatment & Result \\
\hline $140 / 90$ & $\begin{array}{l}\text { Positive } \\
\text { (Fig. 3) }\end{array}$ & R. cerebral & $\begin{array}{l}\text { Radiotherapy (1946) without } \\
\text { benefit. } 1948 \text { R. com. } \\
\text { carotid ligated and divided }\end{array}$ & $\begin{array}{l}\text { Follow-up } 18 \text { months. No } \\
\text { further attacks subarachnoid } \\
\text { bleeding which had been } \\
\text { recurrent since age } 8 \text { years }\end{array}$ \\
\hline - & Positive & L. frontal & Ligation L. com. carotid & $\begin{array}{l}3 \text { year follow-up. No further } \\
\text { bleeding }\end{array}$ \\
\hline $106 / 56$ & Positive & L. frontal & Ligation $L$. internal carotid & $\begin{array}{l}\text { R. hemiparesis and anomia } \\
10 \text { hours later lasting } 24 \\
\text { hours. Recent case }\end{array}$ \\
\hline $120 / 70$ & $\begin{array}{l}\text { Positive } \\
\text { (Fig. 4) }\end{array}$ & R. parietal & Ligation $R$. com. carotid & $\begin{array}{l}3 \text { year follow-up ; occasional } \\
\text { petit mal seizure }\end{array}$ \\
\hline $140 / 95$ & Not done & R. frontal & $\begin{array}{l}\text { R. frontal craniotomy. } R \text {. } \\
\text { com. carotid ligated }\end{array}$ & $\begin{array}{l}2 \text { year follow-up : improved. } \\
\text { Extensive } R \text {. vascular mal- } \\
\text { formation }\end{array}$ \\
\hline $130 / 90$ & Positive & L. fronto-temporal & $\begin{array}{l}\text { Decompression. Radio- } \\
\text { therapy. Ligation L. com. } \\
\text { carotid artery }\end{array}$ & $\begin{array}{l}10 \text { year follow-up. Continues } \\
\text { to have convulsions }\end{array}$ \\
\hline $120 / 70$ & $\begin{array}{l}\text { Positive } \\
\text { (Fig. 5) }\end{array}$ & R. fronto-parietal & $\begin{array}{l}\text { Craniotomy : } 2 \text { weeks later } \\
\text { ligation and division } R . \\
\text { com. carotid }\end{array}$ & Improved at time of discharge \\
\hline $160 / 90$ & Positive & R. post-parietal & Ligation R. com. carotid & $\begin{array}{l}3 \text { year follow-up ; remains } \\
\text { well }\end{array}$ \\
\hline $100 / 62$ & Positive & R. temporal & $\begin{array}{l}\text { Ligation and division } R \text {. com. } \\
\text { carotid }\end{array}$ & Recent case (18.3.50) \\
\hline
\end{tabular}

ARTERIOVENOUS FISTULAS

\begin{tabular}{|c|c|c|c|}
\hline Arteriogram & Treatment & Result & Remarks \\
\hline Not done & $\begin{array}{l}\text { R. com. carotid ligated } \\
\text { and divided }\end{array}$ & Excellent. 1 year follow-up & $\begin{array}{l}2 \text { weeks after ligation } L \text {. hemiparesis } \\
\text { lasting a few days }\end{array}$ \\
\hline $\begin{array}{l}\text { Positive } \\
\text { (Fig. 6) }\end{array}$ & L. com. carotid ligated & Improved for 4 years & $\begin{array}{l}\text { Recurrence of ptosis for } 1 \text { week } \\
4 \text { years later, but improved after } \\
10 \text { days. Has remained well for } \\
5 \text { years since }\end{array}$ \\
\hline Positive & R. com. carotid ligated & $\begin{array}{l}\text { Immediate relief of symptoms. No } \\
\text { follow-up }\end{array}$ & - \\
\hline Not done & L. com. carotid ligated & $\begin{array}{l}\text { Excellent. Bruit and eye signs } \\
\text { recovered }\end{array}$ & $\begin{array}{l}\text { R. brachial monoplegia developed } 6 \\
\text { hours later, and lasted } 24 \text { hours }\end{array}$ \\
\hline
\end{tabular}


This patient had had symptoms for at least 25 years. In retrospect, the correct diagnosis might have been made pre-operatively. A bruit was heard in three of our patients.

In five patients the common carotid artery was ligated ; in three the common carotid was ligated and divided between ligatures; in one patient the internal carotid artery was ligated. Case 18 had had many episodes of subarachnoid bleeding starting in early life. An arteriogram was done in 1946. This was followed by high voltage $x$-ray therapy. In spite of this the patient had recurrence of her subarachnoid bleeding and she was re-admitted in 1948 in stupor. The cerebrospinal fluid was bloody. The arteriogram was repeated, again demonstrating the vascular malformation. Its appearance had not been altered by $x$-ray therapy. During this admission the right common carotid artery was ligated and divided. There have been no episodes of subarachnoid bleeding since, now 18 months. Case 23 had had symptoms of neurological disorder since the age of 3 . At the age of 17 he had subarachnoid bleeding and was in stupor. An arteriogram demonstrated the vascular malformation. Decompression was done, and radiotherapy given. He improved but continued to have seizures. A few years later the left common carotid artery was ligated but his seizures continued. He has had no further subarachnoid bleeding but the seizures have persisted.

Uniformly good results were obtained in four cases of carotid-cavernous sinus fistulas treated by ligating the common carotid artery in two cases and by doubly ligating and dividing the common carotid in the other two (Table III). Three of the carotid-cavernous fistulas were of traumatic origin ; the fourth occurred spontaneously in a 70-year-old arteriosclerotic woman. An intracranial bruit was present in all four patients. In Case 29 the patient complained of headache and head noises. For several weeks he had been treated in another hospital for a psychoneurosis. Following arteriography his common carotid artery was ligated and his symptoms disappeared at once.

The operative mortality and morbidity of ligation of the common carotid artery for aneurysms and vascular malformations compare favourably with that reported following intracranial procedures. The late results, as far as they have gone, apparently are as good. More years of observation will be necessary to provide a final answer. Should follow- up studies by other observers substantiate our observations and results, the simplicity of the carotid ligation should weigh heavily in its favour.

\section{Summary}

The results of ligation of the common carotid artery in the neck in 30 cases have been presented. There were 17 aneurysms of the circle of Willis, nine vascular malformations of the hemispheres, and four carotid-cavernous sinus fistulas.

In the malformation group there was no death ; one patient developed a hemiparesis. In no case has bleeding recurred after operation. Two patients continued to have convulsions.

In the aneurysm group there was one death nine hours after ligation. The other deaths in this group followed craniotomy, one after ten days and one after four weeks. There has been no recurrence of bleeding. There was one post-ligation hemiplegia with aphasia.

The mortality, morbidity, and results of this method of treatment compare favourably with other methods advocated.

\section{REFERENCES} Cushing, H., and Bailey, P. (1928). "Tumours Arising
from the Blood Vessels of the Brain." Springfield. Dandy, W. E. (1938). Ann. Surg., 107, 654.

Dial, D. L., and Maurer, G. B. (1937), Amer. J. Surg. 35, 2.

Fetterman, G. H., and Moran, T. J. (1941). Arch

Path., 32, 251.
Garrison, F. H. (1913). “ History of Medicine”, p. 278 Philadelphia.

Hamby, W. B. (1948). J. Amer. med. Ass., 136, 522. Horsley, V. Quoted by Beadles, C. F. (1907). Brain? 30, 285.

Jaeger, R. (1950). J. Amer. med. Ass., 142, 304.

Keevil, J. J. (1949). Brit. J. Surg., 37, 92.

Matas, R. (1909). In Keen's “Surgery ", vol. 5, p. 321. Philadelphia.

Moniz, E. (1934). “ 'L'Angiographie Cérébrale.” Paris.

Olivecrona, H., and Riives, J. (1948). Arch. Neurol. Psychiat., Chicago, 59, 567.

Padget, D. H. (1944). "In Dandy, W. E. “Intracranial Arterial Aneurysms", p. 67. Ithaca, New York.

Pilz, C. (1868). Arch. klin. Chir., 9, 257.

Rogers, L. (1947a). Brain, 70, 171. (1947b). Brit. J. Surg., 35, 43.

Schorstein, J. (1940). Ibid., 28, 50.

Sweet, W. H., and Bennett, H. S. (1948). J. Neurosurg., $5,178$.

Walsh, F. B., and King, A. B. (1942). Arch. Ophthal., Chicago, 27, 1.

Watson, W. L., and Silverstone, S. M. (1939). Ann. Surg., 109, 1.

Wechsler, I. S., and Gross, S. W. (1948). J. Amer. med. Ass., 136, 517. 